\title{
New Microstrip Resonator of Nanostructured Materials in a Liquid-Crystal-Based Phase Shifter
}

\author{
A. Attoui, A. Boualleg, and S. Redadaa \\ University of 8 May 1945 , \\ Faculty of Science and Technology, \\ Department of Electronics and Telecommunication, \\ Laboratory of Telecommunications, \\ 24000-BP 401 Guelma, Algeria
}

Nanostructured materials (NsM) are materials with a microstructure, the characteristic length scale of which is of the order of magnitude a few (typically 1-100) nanometres. A nanostructure is a structure of an intermediate size between the microscopic structures and the molecular ones. In this article, we study the properties of $6 \mathrm{~nm}$ liquid crystal (LC)-NsM system that forms highly stable solutions in the nematic liquid crystal 4cyano-4-n-pentylbiphenyl (5CB). The nanostructure is covalently functionalized with 4-sulfanylphenyl-4-[4 (octyloxy) phenyl] benzoate (SOPB), which resembles the structure of the $5 \mathrm{CB}$ molecules. The use of LCs as an NsM with phased array antennas is for steering the beam pattern electronically with high effectiveness, managing to get minimum side-lobe levels and narrow beam widths. Normally, phase shifters are the devices in a phased array antenna that allows the radiated beam to be steered in the direction. The objective of this work is to investigate a phase shifter in a linear antenna array for angle scan. A microstrip antenna array is used since it is simple to be designed and fabricated. Ansoft Designer Software is used to simulate the phase shifter for applications to antenna array with LC directed synthesis of NsM. In our paper, we present a new external command with a new influence of the static magnetic bias field of liquid crystal for shifted radiation pattern.

Наноструктуровані матеріяли (NsM) представляють собою матеріяли із мікроструктурою, характерні довжини якої складають близько декількох (зазвичай 1-100) нанометрів. Наноструктура є структурою проміжного розміру між мікроскопічними та молекулярними структурами. У цій статті ми вивчаємо властивості системи рідкий кристал (LC)NsM розміром у 6 нм, яка утворює високостабільні розчини в нематичному рідкому кристалі 4-ціано-4-н-пентілбіфеніла (5СВ). Наноструктуру ковалентно функціоналізовано із 4-сульфанілфеніл-4-[4 (октілоксі) 
феніл] бензоатом (SOPB), який нагадує структуру молекул 5СB. Використання LCs як NsM із антенами 3 фазованою гратницею призначається для управління жмутом електронним способом, із високою ефективністю уможливлюючи одержати мінімальні рівні бічних пелюсток і вузькі ширини променя. Зазвичай фазообертачі являють собою пристрої у фазованій антенній гратниці, що уможливлюе керувати випромінюваним променем за напрямком. Метою цієї роботи є дослідження фазового зсуву в лінійній антенній гратниці для сканування кута. Використовується мікросмужкова антенна гратниця, оскільки вона є простою у проєктуванні та виготовленні. Ansoft Designer Software використовується для моделювання фазового зсуву задля застосувань в антенній Iратниці із синтезою NsM, спрямованою LC. У нашій статті ми представляємо нову зовнішню команду з новим впливом статичного підмагнетувального поля рідкого кристалу задля зміщення діяграми спрямованости.

Наноструктурированные материалы (NsM) представляют собой материалы с микроструктурой, характерные длины которой составляют порядка нескольких (обычно 1-100) нанометров. Наноструктура представляет собой структуру промежуточного размера между микроскопическими и молекулярными структурами. В этой статье мы изучаем свойства системы жидкий кристалл (LC)-NsM размером в 6 нм, которая образует высокостабильные растворы в нематическом жидком кристалле 4-циано-4-н-пентилбифенила (5СB). Наноструктура ковалентно функционализирована с 4-сульфанилфенил-4-[4 (октилокси) фенил] бензоатом (SOPB), который напоминает структуру молекул 5CB. Использование LCs в качестве NsM c антеннами с фазированной решёткой предназначено для управления пучком электронным способом, с высокой эффективностью позволяя получить минимальные уровни боковых лепестков и узкую ширину луча. Обычно фазовращатели представляют собой устройства в фазированной антенной решётке, что позволяет управлять излучаемым лучом по направлению. Целью этой работы является исследование фазового сдвига в линейной антенной решётке для сканирования угла. Используется микрополосковая антенная решётка, поскольку она проста в проектировании и изготовлении. Ansoft Designer Software используется для моделирования фазового сдвига ради приложений в антенной решётке с синтезом NsM, направленным LC. B нашей статье мы представляем новую внешнюю команду с новым влиянием статического подмагничивающего поля жидкого кристалла для смещения диаграммы направленности.

Key words: nanostructured material, liquid crystal, phased array, phase shifter, microstrip antenna.

Ключові слова: наноструктурований матеріял, рідкий кристал, фазована антенна гратниця, фазообертач, мікросмужкова антена.

Ключевые слова: наноструктурированный материал, жидкий кристалл, фазированная антенная решётка, фазовращатель, микрополосковая антенна. 


\section{INTRODUCTION}

Frequency agile devices can be realized using semiconductors, MEMS, ferrites, or ferroelectrics. In this paper, the use of NsM in LC as a tuneable microwave substrate is described. Up to now, the dielectric anisotropy of the permittivity and its electrostatic tenability of the LC molecules are mainly used in an inverted microstrip transmission line technique $[1,2]$.

A simple and inexpensive device has been designed to change the phase of the signal to enter a microstrip-electronic scanning antenna, where the phase change power influences on the beam direction. The general structure of the antenna network with electronic scanning is schematically presented in Fig. 1. After this, it is possible to integrate the phase shifter to the supply line of the printed antenna.

The use of the LC-NsM as a ground plane integrates the phase shifter to the line, and the change in phase of the signal power is obtained by the action of the static magnetic field applied to the LC of NsM.

The choice of these phase shifters is justified by the following benefits: a good frequency response, a low stray radiation, and a simple realization.

Scan Angle $\boldsymbol{\Theta}$

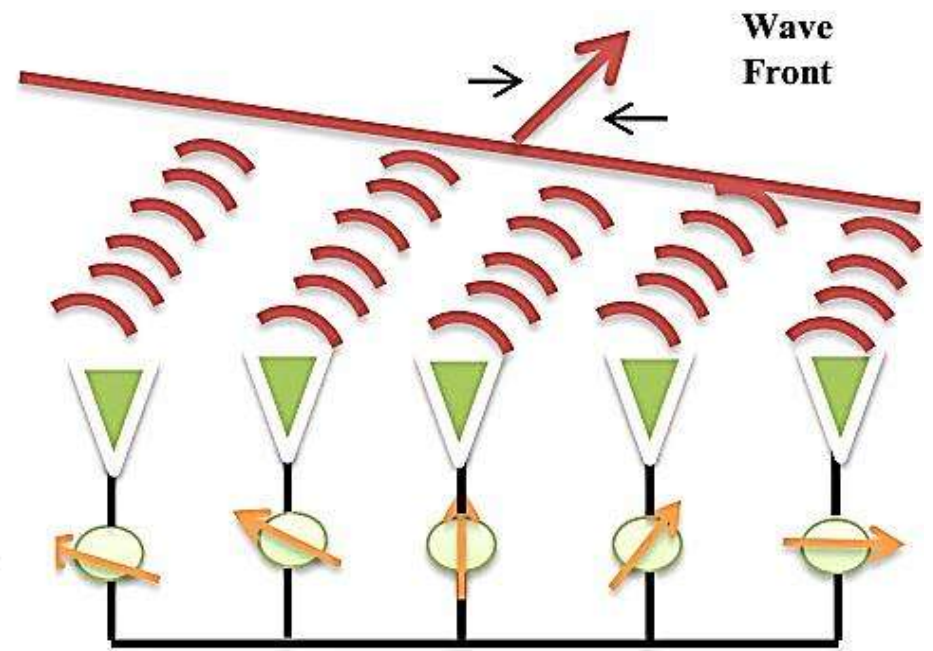

Antenna

elements

Phase Shifters with

LC-NsM

Fig. 1. Array antenna. 


\subsection{Nanostructured Materials (NsM)}

Nanostructured materials may be defined as those materials whose structural elements-clusters, crystallites or molecules-have dimensions within the range of 1-100 $\mathrm{nm}$. The explosion in both academic and industrial interest in these materials over the past decade arises from the remarkable variations in fundamental electrical, optical and magnetic properties that occur as one progresses from an 'infinitely extended' solid to a particle of material consisting of a countable number of atoms. This review details recent advances in the synthesis and investigation of functional nanostructured materials, focusing on those novel size-dependent physics and chemistry results when electrons are confined within the nanoscale semiconductor and metal clusters and colloids. Carbon-based nanomaterials and nanostructures including fullerenes and nanotubes play an increasingly pervasive role in the nanoscale science and technology and, thus, are described in some depth. Current nanodevice fabrication methods and the future prospects for nanostructured materials and nanodevices are discussed [3].

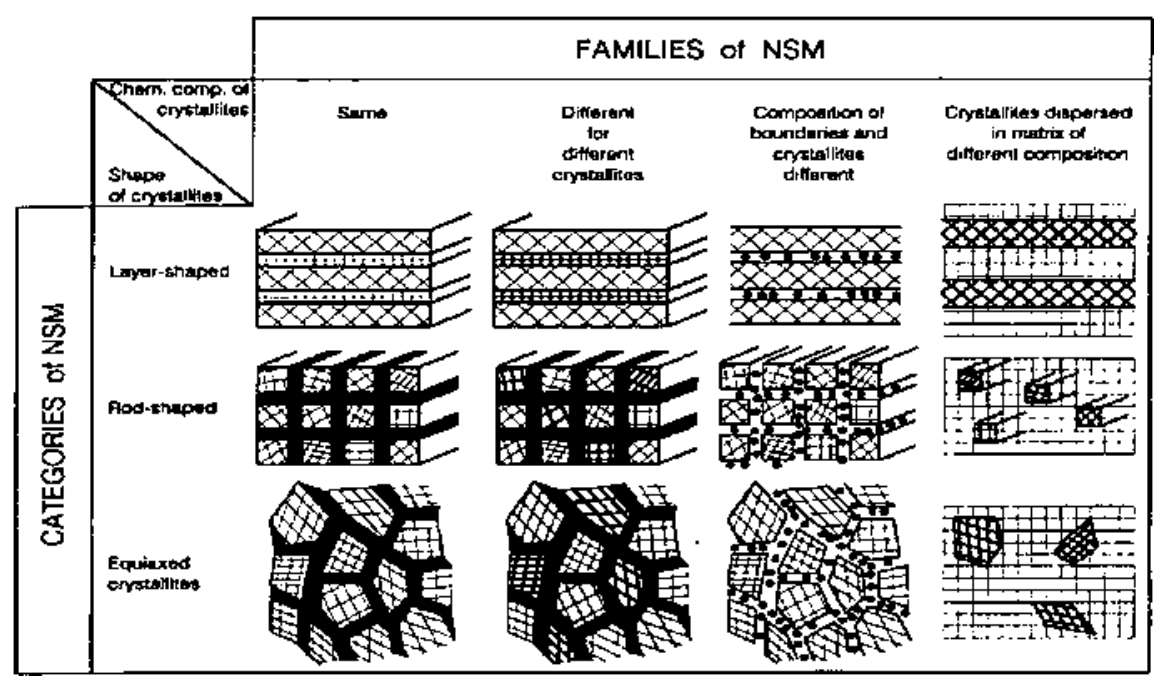

Fig. 2. Classification schema for NsM according to their chemical composition and the dimensionality (shape) of the crystallites (structural elements) is forming the NsM. The boundary regions of the rest and second family of NsM are indicated in black to emphasize the deferent atomic arrangements in the crystallites and in the boundaries. The chemical composition of the (black) boundary regions and the crystallites is identical in the rest family. In the second family, the (black) boundaries are the regions where two crystals of deferent chemical composition are joined together causing a steep concentration gradient [3]. 


\section{THEORETICAL DETAILS}

\subsection{Liquid Crystal Modelling}

In this study, we present LC. Under the applications, we use the LC nematic phase in an ambient temperature. The nematic LCs are characterized by their centre of mass of the molecules showing no order of position. However, molecules procure an orientation order in case of a long distance. Their long-distance and long axes are parallel to an average direction defined by the director vector $\mathbf{n}$ (Fig. 3) [1, 4].
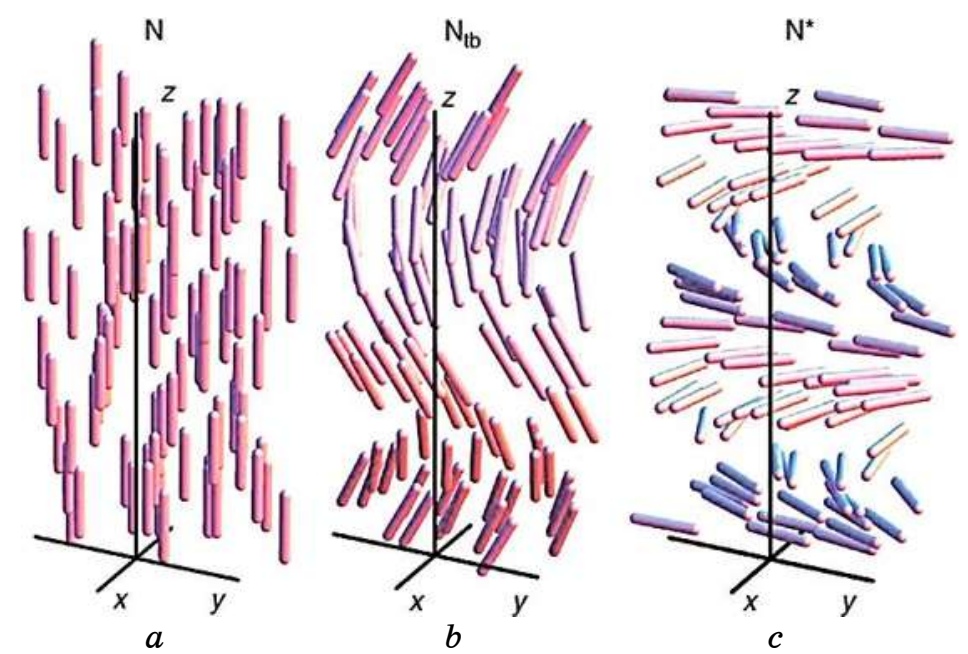

Fig. 3. Representation of molecules CL in a nematic phase.

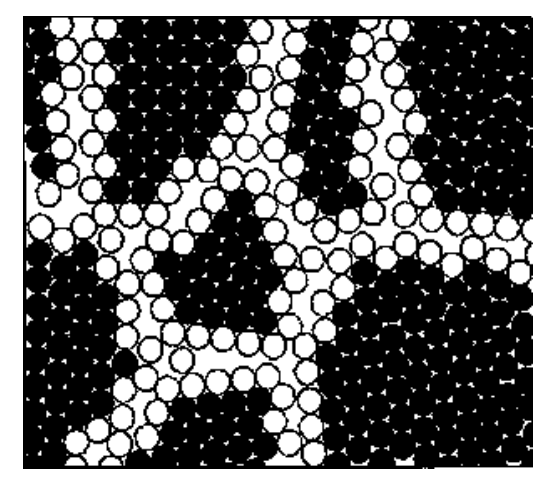

Fig. 4. Two-dimensional model of a nanostructured material. The atoms in the centres (sites) of the crystals are indicated in black. The ones in the boundary core regions are represented as open circles [3]. 


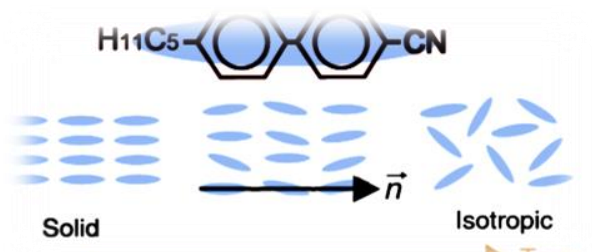

Fig. 5. Representation of the CL molecules in a nematic phase.

TABLE. Characteristics of a liquid crystal [1].

\begin{tabular}{c|c|c|c|c}
\hline $\mathrm{CL}$ & $\varepsilon_{\perp}^{\prime}$ & $\tan \delta_{\perp}$ & $\varepsilon_{\|}^{\prime}$ & $\tan \delta_{\|}$ \\
\hline $5 \mathrm{CB}$ & 2.64 & 0.031 & 2.98 & 0.014 \\
\hline
\end{tabular}

In this phase, the LCs are anisotropic materials with complex permittivity presented in the form of a tightening [1]:

$$
\varepsilon^{*}=\left[\begin{array}{ccc}
\varepsilon_{\|}^{*} & 0 & 0 \\
0 & \varepsilon_{\perp}^{*} & 0 \\
0 & 0 & \varepsilon_{\perp}^{*}
\end{array}\right] .
$$

The dielectric anisotropy is defined by the following equation:

$$
\Delta \varepsilon=\varepsilon_{\|}^{\prime}-\varepsilon_{\perp}^{\prime} .
$$

Here, $\Delta \varepsilon$ is a dielectric anisotropy, $\varepsilon_{\|}^{\prime}-\mathrm{LC}$ permittivity with DC voltage, $\varepsilon_{\perp}^{\prime}-$ LC permittivity without $\mathrm{DC}$ voltage.

The liquid crystal is simulated as K15 (5cb), which exhibits only the nematic phase between $22.5^{\circ}$ and $35^{\circ}$. Figure 5 shows the dielectric characterization of $\mathrm{K} 15$ at room temperature [1, 2].

The characteristics of liquid crystals are summarized in Table.

\subsection{Phase Shifter Agile Frequency Liquid Crystal Substrate}

The order of liquid crystal within the microwave substrate in the case of classic line microstrip is reached between input and output, the gap is fixed at a given frequency. This phase shift depends on both the effective permittivity and the line length as follows:

$$
Q=\frac{360 L F \sqrt{\varepsilon_{\text {reff }}}}{c} .
$$




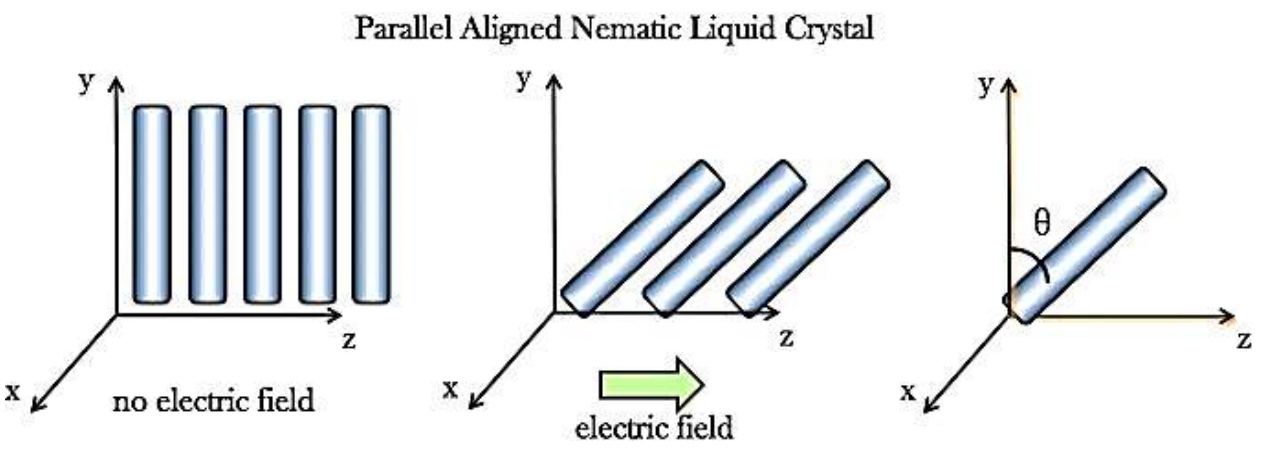

Fig. 6. Influence of the electric field command on the orientation of liquidcrystal molecules.

When we use the substrate of a liquid-crystal structure defined above, it will be possible to vary the effective permittivity on the substrate using, in addition to the microwave signal, a lowfrequency voltage command (Fig. 6) [1, 4-7].

The permittivity seen by the microwave signal is noted as $\varepsilon_{\text {reff }}(0)$. This permittivity is related mainly to the permittivity of a liquid crystal, $\varepsilon_{r \perp}$. Because of electric-field command, the molecules of a liquid crystal will gradually move perpendicular to the electrodes (n $\perp \mathbf{E})$ to saturation permittivity. $\varepsilon_{r e f f}(\mathbf{E})$ is related mainly to the liquid crystal permittivity $\varepsilon_{r \|}$.

The variation of permittivity will induce the change in the wavelength guided; therefore, the change in phase is given by the following relationship $[1,4,5,9]$ :

$$
\Delta \Phi=-\frac{360 L F\left(\sqrt{\varepsilon_{\text {reff }}(\mathbf{E})}-\sqrt{\varepsilon_{\text {reff }}(\mathbf{0})}\right)}{c} .
$$

\subsection{Presentation of the Resonator-Based Phase Shifters}

The prototype nematic LC structure of high dielectric anisotropy from 2.7 to 2.9 is given by $\mathrm{K} 15$ (5CB) of Merck. Then, the focus will be on the dimensional requirements for the phase shifter in order to get a resonance frequency at $38 \mathrm{GHz}$. The considered geometry (Figs. 7-9) consists of three elements: ground plane composed of gaps (which are filled by a liquid crystal), conductor, and substrate.

The wave propagation is not affected; the field is more concentrated in the LC. The application of DC voltage to the LC, we arbitrarily set the resonance frequency to $38 \mathrm{GHz}$. 


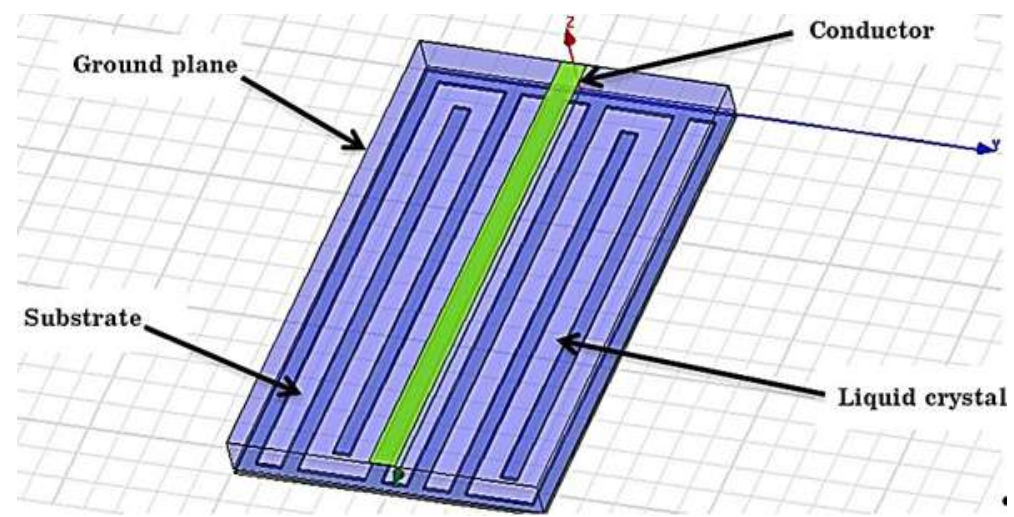

Fig. 7. Structure of a microstrip resonator.

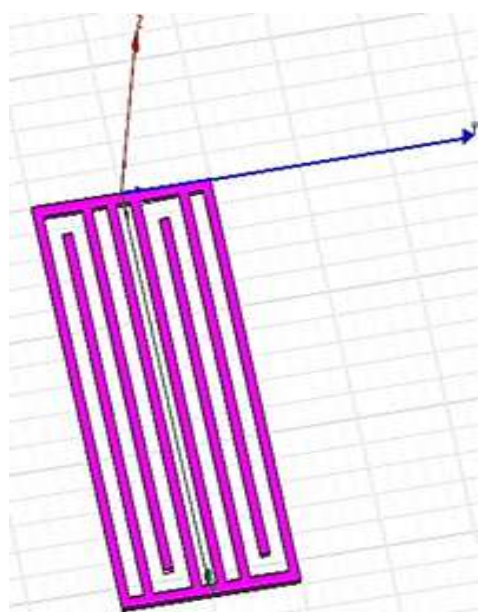

Fig. 8. Structure of a ground plane.

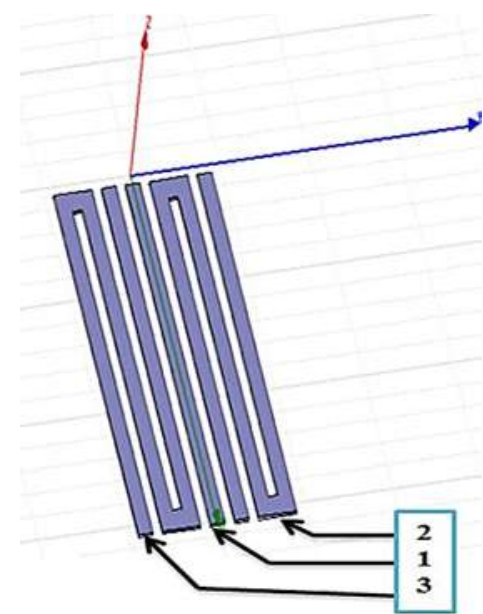

Fig. 9. Structure of the LC parts.

\section{RESULTS AND DISCUSSION}

The simulation is performed in the frequency range $30-50 \mathrm{GHz}$ to obtain the resonator characteristics. The obtained results were computed using Ansoft HFSS 14. The purpose of the present study was to establish the effect of varying the NsM (LC) permittivity material and anisotropy value on the phase range and the reflection loss.

Simulations were performed for the change in LC permittivity of the material from the proposed LC parts corresponding to the LC material, which was used. As the permittivity value is swept the beam, the substrate is realized by DUROID 4003. The NsM-liquid crystal is introduced between the ground plane gaps. These results 


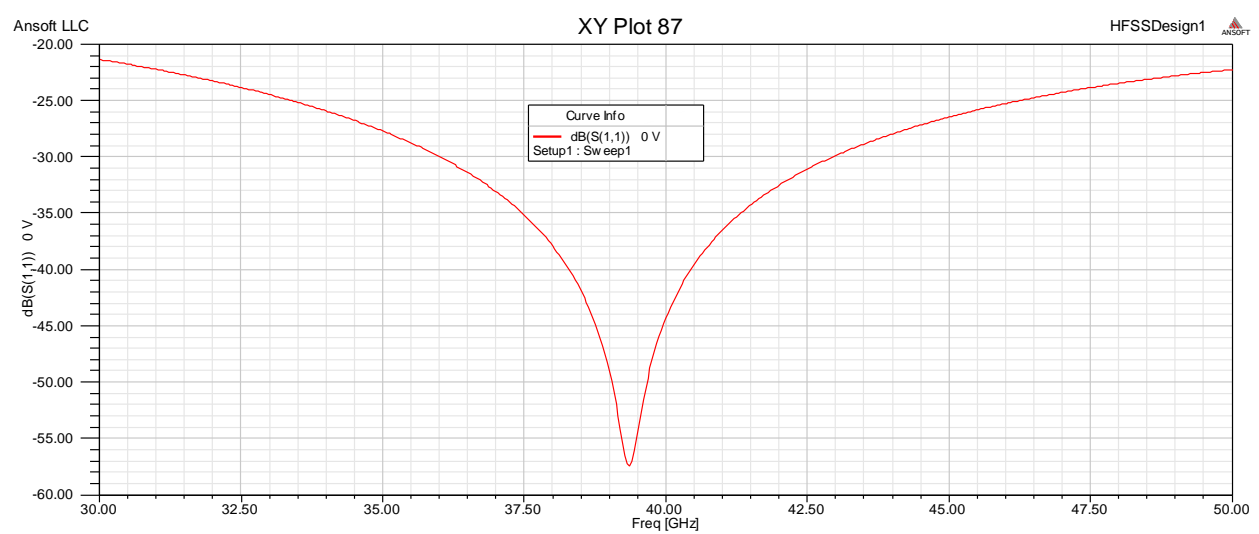

Fig. 10. Simulated reflection loss (S11).

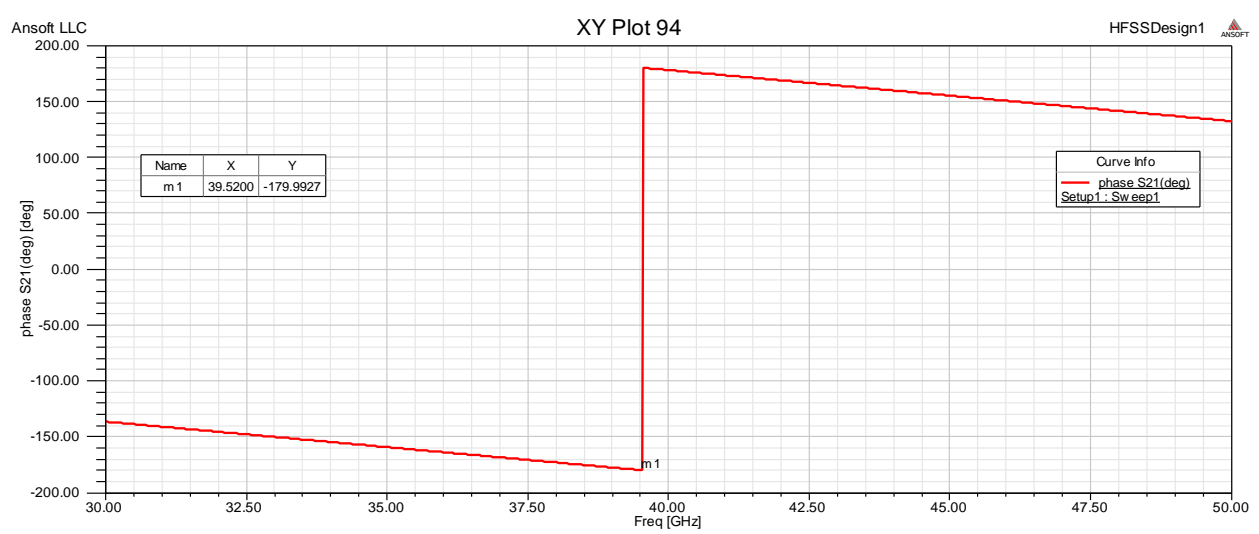

Fig. 11. Phase angle $|\mathrm{S} 21|$ [in degrees] of resonator.

were simulated with and without driving voltage $(0 \mathrm{~V}$ and $7 \mathrm{~V})$.

Figure 10 illustrates the simulated results of the return losses without applied DC voltage. In Figure 10, it can be seen that the simulated return loss achieved $-58 \mathrm{~dB}$ from 38 to $40 \mathrm{GHz}$.

Figure 11 depict the simulated results of phase angle $|\mathrm{S} 21|$ [in degrees] of resonator.

Figure 12 shows the results of resonance frequency simulation, with and without control voltage. It is noticeable that the resonance frequency of beat for an applied electric field of $7 \mathrm{~V}$.

This variation of resonance frequency data may result from the gap in the precision of the values found for the LC dielectric permittivity.

According to Figure 12, the simulated return loss achieved $-66.1256 \mathrm{~dB}$ for $38.76 \mathrm{GHz}$ and $53.1208 \mathrm{~dB}$ for $39.76 \mathrm{GHz}$. The 


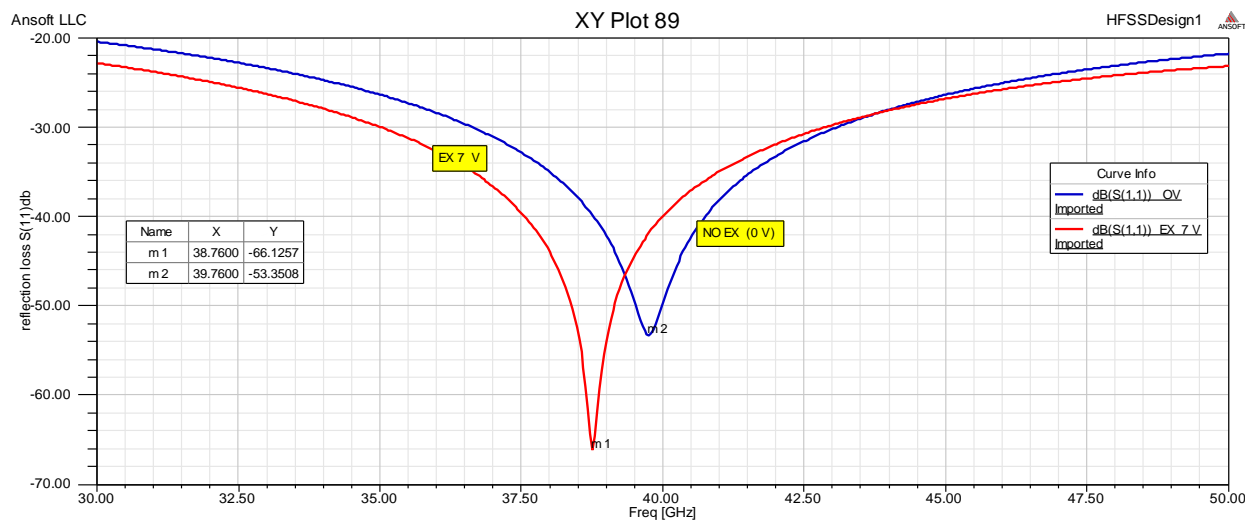

Fig. 12. Measured reflection loss at two different voltage states.

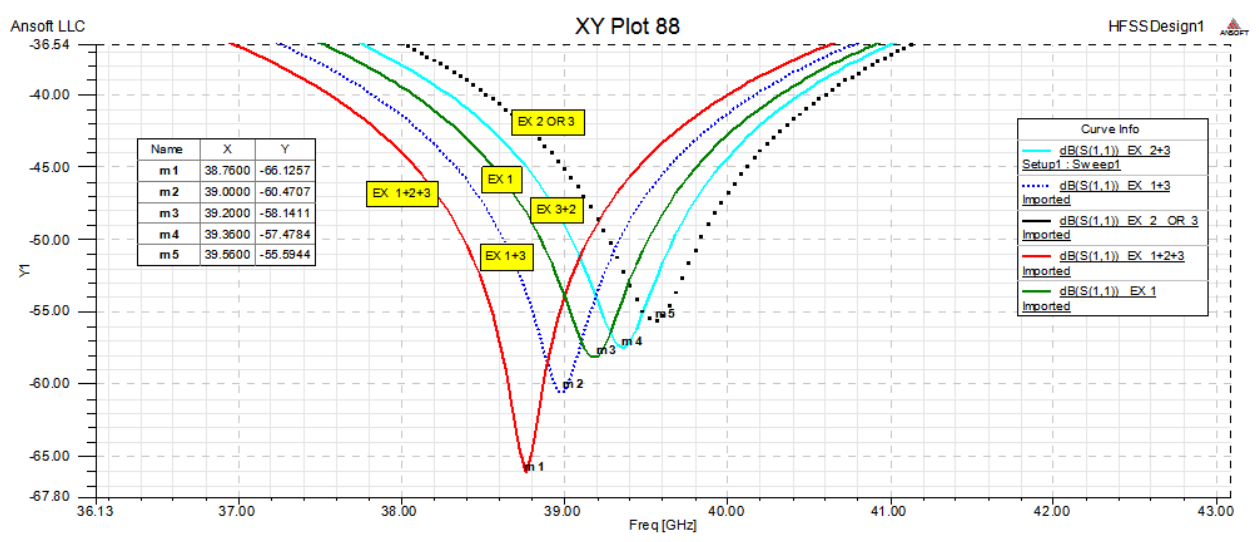

Fig. 13. Measured reflection loss at different excitation positions of voltage states.

resonance frequency variation $\left(\Delta \mathrm{F}_{r}\right)$ is of $1 \mathrm{GHz}$.

Figure 13 demonstrates the resonance frequency obtained from the excitations positions. This Figure gives the evolution variation of reflection loss (S11) depending on excitation position.

Corresponding to the comparison between excitation position voltage (EX 2 or 3 ) and (EX $1+2+3)$, at an applied electric field of $7 \mathrm{~V}$ shown in Fig. 13, the obtained value of the loss difference is $10.5313 \mathrm{~dB}$, and variation of resonance frequency is 0.8 .

\section{CONCLUSION}

We presented a study on the resonator of nanostructured materials 
in a liquid crystal based on the influence of the external excitation tension.

The proposed structure based on three parts of LC-NsM were designed and simulated. The resonance frequency variation confirmed the frequency adjustment ability of LC-NsM based devices; the extent of adjustment depends on the LC anisotropy. The simulation of reflection return loss has been greatly improved by about $10 \mathrm{~dB}$ along with the variation of the simulation resonance frequency of 1 $\mathrm{GHz}$.

\section{REFERENCES}

1. A. Attoui and A. Boualleg, Metallurgical and Mining Industry, 7: 134 (2015).

2. S. Missaoui, A. Gharbi, and M. Kaddour, Journal of Chemical Engineering and Materials Science, 2, No. 7: 96 (2011).

3. H. Gleiter, Acta Metallurgica, 48, Iss. 1: 1 (2000).

4. S. Mueller, C. Felber, P. Scheele, M. Wittek, C. Hock, and R. Jakoby, European Microwave Conference (2005), vol. 1, p. 1.

5. F. A. Tahir and H. Aubert, Progress in Electromagnetics Research, 144: 1 (2010).

6. V. A. Tolmachev, V. A. Melnikov, A. V. Baldycheva, K. Berwick, and T. S. Perova, Progress in Electromagnetics Research, 122: 293 (2012).

7. Y. T. Kim, Journal of the Korean Physical Society, 49, No. 3: 1143 (2006).

8. B. A. Belyaev, A. A. Leksikov, A. M. Serzhantov, and V. F. Shabanov, Technical Physics Letters, 34, No. 6: 463 (2008).

9. Z. Du, V. Viikari, J. A. Laurinaho, A. Tamminen, and A. V. Raëais Aëanen, Progress in Electromagnetics Research, 148: 15 (2014).

10. F. Sahbani, N. Lemcel Tentillier, A. Gharsallah, and A. Gharbi, IEEE $3^{\text {rd }}$ International Design and Test Workshop-IDT 2008 (2008), No. 978-14244-3477-0/08/25.00, p. 78.

11. P. Anand, S. Sharma, D. Sood, and C. C. Tripathi, $1^{\text {st }}$ International Conference ET2ECN-2012 (2012), vols. 1-3, No.978-1-4673-1627-9/12/31.00, p. 8. 